\title{
Islamic moral values of pre-service teachers for secondary schools ${ }^{1}$
}

\author{
Osman Titrek ${ }^{2}$ \\ Münevver Yalçınkaya ${ }^{3}$ \\ Mustafa Bayrakci ${ }^{4}$
}

\begin{abstract}
The aim of this study is to determine whether there is a significant difference in Islamic moral values of pre-service teachers in secondary schools according to their gender, educational departments, universities, parents' educational level, parents' economical level and region. Survey model is carried out in this study. The participants of the study are composed of 554 pre-service teachers from Sakarya University and Aegean University. The data were collected by a five-point Likert scale Islamic Moral Values and analyzed with SPSS. As a result of the study, it is seen that there is a significant difference between the Islamic moral values of pre-service teachers according to their educational departments, universities, parents' educational level, parents' economical level and region. On the other hand, there isn't a significant difference between the Islamic moral values of pre-service teachers according to their gender.
\end{abstract}

Key Words: Moral, Ethics, Values, Islamic Moral

\section{Introduction}

One of the most important features that separate the societies from each other is their own culture and language and belief unities among the people belong to a society. In forming that culture mentioned above and developing the moral values, the religion that the society accepts, has an important role. Beliefs in Muslim societies have important effects on the culture and lifestyle like in all societies. In the Muslim societies, the effect of the Islamic religion on their tradition, literature, art and moral values is seen (Asikoglu, 2000).

${ }^{1}$ This paper presented at 15 th International Conference Educational Reform in the $21^{\text {st }}$ Century in Balkan Countries ${ }^{2}$ Assoc. Prof. Dr., Sakarya University, Faculty of Education, Department of Educational Sciences, otitrek@sakarya.edu.tr

3Prof. Dr., Ege University, Faculty of Education, Department of Educational Sciences, munevver.yalcinkaya@,ege.edu.tr

${ }^{4}$ Assist. Prof. Dr., Sakarya University, Faculty of Education, Department of Educational Sciences, mbayrakci@sakarya.edu.tr 
Titrek, O., Yalçınkaya, M., \& Bayrakcı, M. (2014). Islamic moral values of pre-service teachers for secondary schools. International Journal of Human Sciences, 11(1), 469-480. doi: 10.14687/ijhs.v11i1.2831

The religion of the society has an important role in the forming of the moral values. For instance, Christianity affects the people's lifestyle in the west (Asikoglu, 1999). According to the Koran, individuals form the moral. However, an individual isn't the source and measure of the moral (Cetinkaya, 2007). Any values we describe as "moral" may mean regional, political, social value, too. For example respecting to others' thoughts is the requirement of both science and moral. Moreover that respect can be described as both political and social value. (Uysal, 2003). Meaning of the moral in Turkish is "moral" in Latin (Yurutucu \& Gurbuz, 2001). Moral is a judgment that is right or wrong. Although, that judgment depends on values, that is not a value. (Aydin, 2011)

Moral in Islam is to behave in a way that Koran and Prophet Mohammad recommend and avoid behaving in a way that they forbid. Some principles that are so important in Islamic moral and affect the society deeply are:

-Behaving the people well and wishing the blessing

-Concealing the faults

-Being honest and not lying

It is better to define the word "ethics" derived from the word "hulk" in Arabic and often used instead of moral in Turkish that means habit, natural tendency, and character. Ethics asks the questions about the qualified situation that changes an action into a good action in the point of moral. It discusses the words such as moral, good, duty, necessity, permission into details. In other words, while moral identifies cultural values, true or false about ideal, and how to behave according to these, ethics depends on more abstract concepts and tries to identify what to understand from the abstract concepts. (Altinkurt, Yllmaz, 2011). Ethics is one of the main parts of the philosophy and science as a topic about moral, behaviors, action and judgments. Moral is about true-false, good-bad, virtue-fault, behaviors and evaluating the results of the behaviors (Aydin I., 2003).

In the last years, one of the most important issues is professional ethics. Ethical principles about several professions have been defined and the members have been supposed to obey these principles. Professional ethics is identified as behavioral rules at the jobs directly depend on human. (Altinkurt \& Yilmaz, 2011). When we consider ethics of teaching profession, there are some principles such as being professional, responsibility in the profession, justice, equality, providing a healthy and safe environment, not stealing, being honest, being objective, 
Titrek, O., Yalçınkaya, M., \& Bayrakcı, M. (2014). Islamic moral values of pre-service teachers for secondary schools. International Journal of Human Sciences, 11(1), 469-480. doi: 10.14687/ijhs.v11i1.2831

professional dependence and progressing continuously, respect, effective usage of the resources. (Aydin, 2003)

Individuals learn social rules, differing good-bad, true-false with the help of traditions and having a measurement according to their own moral principles. This measurement forms opinions and beliefs (Yazici, 2006). Some of the main elements which enable society to control individuals and enable individuals to control society are these values. (Yazici, 2006) Value as a term was derived from the word "valere" in Latin its meaning is "being precious", "being strong". (Aydin, 2011) Although "values" have been discussed in detail as a term, it is hard to say that its content is clear. However, "values" as a term can be made concrete as point of view, the human, thinking over today and tomorrow (Dilmac, Bozgeyikli, Cikili, 2008).

Values, which are very important for all the social branches, have been discussed by various disciplines and put forward a lot of definitions according to their starting point. (Aydin, 2011) As a term, "value" means standards and principles that form our judgments about objects, people, thoughts, situations and actions as good-bad, desired-undesired (Yazici, 2006). Value is a belief that determines the importance of presence or event for people.

The most important function of values is shaping and determining social life (Aydin, 2011). Values have an important role in understanding humans' behaviors (Yurutucu \& Gurbuz, 2001). It is important to know about how pre-service teaches socialize as the teachers of the future. In other words, it is important to know about their systems of values. (Dilmac, Bozgeyikli, Cikili, 2008)

Lots of classifications have been done so far in order to carry out the studies on values. Nelson's, Rokeach's, Spronger's and Schwartz's are the most known and accepted ones. According to Nelson values are classified into three groups as individual values, group values, and social values. While individual values are relevant to our individual preferences, group values mean the values shared by the members of a specific group and social values mean justice, respect, difference, equality, etc. Rokeach classifies the values as basic values and means values. Basic values mean decisive values and means values mean the behavioral manner in order to reach the decisive values. Spranger classifies the values as scientific values, economic values, esthetic values, social values, political values and religious values (Yazici, 2006) 
Titrek, O., Yalçınkaya, M., \& Bayrakcı, M. (2014). Islamic moral values of pre-service teachers for secondary schools. International Journal of Human Sciences, 11(1), 469-480. doi: 10.14687/ijhs.v11i1.2831

"Values" is also a concept that includes something holy honesty having honor, being helpful are something holy and exalt individuals who have Thus, while defining something as good-bad means its moral values, defining something beautiful-ugly means its esthetic values. (Uysal, 2003)

One of the main aims of making researches about values is to define the tendencies and attitudes, behaviors, social experiences and roles. Values affect people's attitudes and behaviors. Moreover, values designate and lead people's behaviors. This is very important because especially teachers' values affect students' behaviors. (Kulaksizoglu \& Dilmac, 2000). It's so important to know how teachers of the future socialize. In other words, it is important to know the system Islamic moral values of a society \%99 of whom are Muslim. (Dilmac, Bozgeyikli,Cikili, 2008). In the literature, we see some research about pre-service teacher's values related democratic values (Uygun,2009; Yiğit \& Çolak, 2010; Zehir Topkaya \& Yavuz, 2011); ethic values (Ünal, 2011; Altınkurt \& Yilmaz, 2011; Pelit \& Güçer, 2006; Yazar, 2012). Hovever we can not see any research about religional values and it's evaluation in Turkey. When we examine the literature; Francis, Jones and Craig (2004) tried to measure Christianity values and beliefs in the west and after then Francis, Şahin and Alfailakawi (2008) have started to determine Islamic values of young adults in Kuwait. After then, Ok (2011) tried to develop a scale measuring Islamic values. Still, this process is continuing and there is no research about Islamic values of teacher's and pre-service teachers. We can claim that not only democratic and ethic values but also Islamic values affecting preservice and in service teachers practises in clasrooms. That's why, determining Islamic values can be an important research nowadays. Thus, following sub-problems are going to be investigated:

1) What is the level of pre-service teachers' Islamic moral values?

2) Is there a significant difference between pre-service teachers' Islamic moral values according to their a. universities, b. gender, c. departments, d. mothers' educational levels, e. fathers' educational levels, f. families' economic level, g. region?

\section{Methodology}

The participants in this study were 554 pre-service teachers from Sakarya University $(n=329)$ and Aegean University ( $\mathrm{n}=225)$. The participants were recruited by visiting classes and asking for volunteers from universities' education faculties. One questionnaire; "Islamic Moral Values" was applied to all participants (see Table 1 for a list of the questions). The pre-service teachers completed the survey in one of two ways: paper format during class, paper format to take home 
Titrek, O., Yalçınkaya, M., \& Bayrakcı, M. (2014). Islamic moral values of pre-service teachers for secondary schools. International Journal of Human Sciences, 11(1), 469-480. doi: 10.14687/ijhs.v11i1.2831

and return. Participants responded on a five-point Likert scale ranging from 1 (never or rarely) to 5 (always).

\section{Findings}

In the findings and comments following, the tables and comments about analyzing the results of sub-problem 1 and sub-problem 2 are explained.

Sub-problem 1. What is the level of Islamic Moral V alues of pre-service teachers?

Table 1: The level of Islamic moral values of pre - service teachers

\begin{tabular}{|c|c|c|}
\hline Islamic Moral Values & SS & $\bar{x}$ \\
\hline $\begin{array}{l}\text { 1. I believe that honesty is always the best, whatever the } \\
\text { consequences are. }\end{array}$ & 1.01 & 4.17 \\
\hline 2. I try to be a good role model for the others. & 1.03 & 3.77 \\
\hline 3. Even if I know it would hurt me, I never hide my mistakes. & 1.07 & 3.84 \\
\hline 4. I feel bad when someone damage the other's belongings. & 1.39 & 3.45 \\
\hline 5. I don't think I am a good role model for the others. & 1.29 & 3.11 \\
\hline 6. I appreciate my friends who get advice from their parents. & 1.04 & 3.76 \\
\hline 7. I never attempt to lie when I experience a critical situation. & 1.11 & 3.78 \\
\hline 8. I feel happy when the others satisfy with my behavior. & 1.36 & 3.51 \\
\hline 9. I don't like listening to advice of elderlies. & 1.27 & 3.41 \\
\hline 10. I hate watching movies whose value of moral is low. & 1.43 & 2.94 \\
\hline 11. I avoid being friends with smokers. & 1.36 & 2.8 \\
\hline 12. I never attempt to cheat in exams. & 1.34 & 2.91 \\
\hline 13. I hate listening to my parents' advices. & 1.41 & 3.29 \\
\hline 14. I participate in works based on being volunteer. & .98 & 4.02 \\
\hline 15. My freedom shouldn't conflict with others' freedom. & .95 & 4.25 \\
\hline 16. I feel sad when the rate of moral crimes increases. & .89 & 4.49 \\
\hline 17. I support the equality of opportunities among the people. & 1.17 & 4.01 \\
\hline Total & $10 / 17=0.59$ & $61 / 17=3.59$ \\
\hline
\end{tabular}

Table 2: Descriptive statistics on attitude towards Islam

\begin{tabular}{lll}
\hline & $\bar{x}$ & SS \\
\hline TOTAL & 91,33 & 26,742 \\
\hline AVERAGE & 3,97 & 1,215 \\
\hline
\end{tabular}


Titrek, O., Yalçınkaya, M., \& Bayrakcı, M. (2014). Islamic moral values of pre-service teachers for secondary schools. International Journal of Human Sciences, 11(1), 469-480. doi: 10.14687/ijhs.v11i1.2831

General arithmetic mean of the level of Islamic Moral Values of pre-service teachers for secondary schools is $61(\bar{x}=3.59)$ and standard deviation is 10 (SS $=0.59)$. According to Table 2 , the arithmetic mean avarage of the questionnaire applied to 554 attendants from Sakarya and Ege Universities, secondary school pre-service teacher ' attitude towards Islam is high $(\bar{x}=3,97$ \& $\mathrm{SS}=1,215)$. When we compared values and attitudes means, attitudes are higher than values.

According to Table 1, the level of Islamic Moral Values of pre-service teachers is high in the items 1-I believe that honesty is always the best, whatever the consequences are $(\overline{\boldsymbol{x}}=4.17), 14-\mathrm{I}$ participate in works based on being volunteer $(\overline{\boldsymbol{x}}=4,02), 15-$ My freedom shouldn't conflict with others' freedom $(\overline{\boldsymbol{x}}=4,25), 16-\mathrm{I}$ feel sad when the rate of moral crimes increases $(\overline{\boldsymbol{x}}=4$, 49 ) and 17-I support the equality of opportunities among the people $(\overline{\boldsymbol{x}}=4,01)$. On the other hand the level of Islamic Moral Values of pre-service teachers is low in the items 10-I hate watching movies whose value of moral is low $(\overline{\boldsymbol{x}}=2,94), 11-\mathrm{I}$ avoid being friends with smokers $(\overline{\boldsymbol{x}}=2,8)$ and $12-$ I never attempt to cheat in exams $(\overline{\boldsymbol{x}}=2,91)$.

Most of the secondary school pre-service teachers declared that they are happy for being a Muslim, they love living in accordance with the tradition of the prophet, they feel closer to God by believing to his existence, they believe that God helps them and other people to have a better life, They believe the Quran is up to date and it inspires them in their life.

Sub-problem 2. Is there a significant difference between pre-service teachers Islamic moral values according to their

a. universities, b. gender,

c. departments, d. mothers' educational levels, e. fathers' educational levels,

f. families' economic level, g. region?

Table 3: t-Test results of the level of Islamic moral values of pre - service teachers according to university variable

\begin{tabular}{|c|c|c|c|c|c|c|c|}
\hline Dimensions & University & $\mathrm{N}$ & $\bar{x}$ & SS & sd & $\mathrm{t}$ & $\mathrm{p}$ \\
\hline \multirow{3}{*}{$\begin{array}{l}\text { The Level of Islamic Moral } \\
\text { Value }\end{array}$} & $\begin{array}{l}\text { Sakarya } \\
\text { University }\end{array}$ & 270 & 65.91 & 9.74 & \multirow{3}{*}{459} & \multirow{3}{*}{13.945} & \multirow{3}{*}{$.000^{*}$} \\
\hline & & & & & & & \\
\hline & $\begin{array}{l}\text { Ege } \\
\text { University }\end{array}$ & 191 & 55.14 & 5.18 & & & \\
\hline \multirow{3}{*}{$\begin{array}{l}\text { The Level of Islamic } \\
\text { Attitudes }\end{array}$} & Sakarya & & & & \multirow{3}{*}{463} & \multirow{3}{*}{6,24} & \multirow{3}{*}{$.000^{*}$} \\
\hline & University & 282 & 90,94 & 12,61 & & & \\
\hline & $\begin{array}{l}\text { Ege } \\
\text { University }\end{array}$ & 183 & 82,77 & 15,45 & & & \\
\hline
\end{tabular}

$* \mathrm{p}<.05$ there is a significant difference 
Titrek, O., Yalçınkaya, M., \& Bayrakcı, M. (2014). Islamic moral values of pre-service teachers for secondary schools. International Journal of Human Sciences, 11(1), 469-480. doi: 10.14687/ijhs.v11i1.2831

As seen in the Table 3, it is clear that there is a significant difference between the levels of Islamic moral values of pre - service teachers according to university variable $\left[\mathrm{t}_{(459)}=13.945 ; \mathrm{p}<0.05\right]$ Sakarya University $(\overline{\boldsymbol{x}}=65.91)$ and Aegean University $(\overline{\boldsymbol{x}}=55.14)$. When the arithmetic mean is analyzed it is seen that the level of Islamic moral values of pre-service teachers in Sakarya University is higher than the pre-service teachers' in Ege University. When we observed attitudes of preservice teachers towards Islam regarding the variable of University, there's a significant difference linked with the university $\left[\mathrm{t}_{(463)=} 6,24 ; \mathrm{p}<0,05\right]$. According to the arithmetic average pre-service teachers in Sakarya University $(\bar{x}=90,94)$ have a modest attitude towards Islam compared to the ones in Ege University $(\bar{x}=82,77)$.

Table 4. t-Test results of the level of islamic moral values of pre - service teachers according to gender variable

\begin{tabular}{|c|c|c|c|c|c|c|c|}
\hline Dimensions & Gender & $\mathbf{N}$ & $\bar{x}$ & SS & Sd & $\mathbf{t}$ & $\mathrm{p}$ \\
\hline \multirow{2}{*}{$\begin{array}{l}\text { The Level of Islamic Moral } \\
\text { Values }\end{array}$} & Male & 106 & 60.22 & 9.70 & \multirow[t]{2}{*}{454} & \multirow[t]{2}{*}{-1.557} & \multirow{2}{*}{.939} \\
\hline & Female & 350 & 61.88 & 9.58 & & & \\
\hline \multirow[b]{2}{*}{ The Level of Islamic Attitudes } & Male & 61 & 99.90 & 16.91 & \multirow[b]{2}{*}{275} & \multirow[b]{2}{*}{,489 } & \multirow[b]{2}{*}{,625 } \\
\hline & Female & 216 & 97.20 & 16.01 & & & \\
\hline
\end{tabular}

As seen in the Table 4, it is seen that there is no significant difference between the levels of Islamic moral values of pre - service teachers according to gender variable $\left[\mathrm{t}_{(454)}=-1.557 ; \mathrm{p}>0.05\right]$, male $(\overline{\boldsymbol{x}}=60.22)$ and female $(\overline{\boldsymbol{x}}=61.88)$.

In Table 2 regarding pre-service teachers' attitude towards Islam there's no significant difference related with gender $\left[\mathrm{t}_{(275)}=, 489 ; \mathrm{p}>0,05\right]$. Analyzing the arithmetic average male pre-service teachers' attitude $(\bar{x}=99,90)$ towards Islam is modest if compared to female ones $(\bar{x}=97,20)$.

Table 5 Analysis of variance results of the level of Islamic moral values of pre - service teachers according to department variable

\begin{tabular}{llcccccc}
\hline Variable & Branche & N & $\overline{\boldsymbol{x}}$ & SS & sd & F & $\begin{array}{c}\text { P } \\
\text { (Tukey) }\end{array}$ \\
\hline Islamic Moral & Science Teach. & 138 & 63.09 & 9.338 & & & $.001 *$ \\
Values & Social Science T. & 270 & 60.03 & 9.833 & 2 & 7.456 & $1-2,2-3$ \\
& Linguistic Teach. & 38 & 64.89 & 8.190 & & & \\
\hline
\end{tabular}

$* \mathrm{p}<0.05$ There is a significant difference. 
Titrek, O., Yalçınkaya, M., \& Bayrakcı, M. (2014). Islamic moral values of pre-service teachers for secondary schools. International Journal of Human Sciences, 11(1), 469-480. doi: 10.14687/ijhs.v11i1.2831

As seen in the Table 5, there is a significant difference between the levels of Islamic moral values of pre - service teachers according to department variable $\left[\mathrm{F}_{(2)}=7.456 ; \mathrm{P}=.001\right]$. According to the Tukey $\mathrm{b}$ analysis done in order to identify the reason of the difference, it is seen that there is a significant difference between the levels of Islamic moral values of pre - service teachers in Science, Social Science and Linguistic. According to the department variable, it is determined that the level of Islamic moral values of pre - service teachers in SBÖ $(\overline{\boldsymbol{x}}=64.89)$ is higher than the pre- service teachers in SNÖ $(\overline{\boldsymbol{x}}=63.09)$.

Table 6 Analysis of variance results of the level of Islamic moral values of pre - service teachers according to demographic variables

\begin{tabular}{|c|c|c|c|c|c|c|c|}
\hline Variable & & $\mathrm{N}$ & $\bar{x}$ & SS & sd & $\mathrm{F}$ & $\begin{array}{c}\mathrm{P} \\
\text { (Tukey) }\end{array}$ \\
\hline \multirow{7}{*}{ Region } & 1.Marmara & 213 & 65.53 & 9,763 & \multirow{7}{*}{5} & \multirow{7}{*}{17.035} & $.000^{*}$ \\
\hline & 2.Mediterranean & 101 & 56.96 & 6,636 & & & $5,1-2$ \\
\hline & 3.Aegean & 68 & 57.15 & 8,066 & & & $4-1,5$ \\
\hline & 4.Central Anatolia & 37 & 56.81 & 8,556 & & & $3-1,5$ \\
\hline & 5.East/Southeast Anat. & 12 & 64.72 & 8,74 & & & $2-1,5$ \\
\hline & 6.Black Sea & 26 & 62.46 & 9,114 & & & \\
\hline & 7.Total & 457 & 61.51 & 9,656 & & & \\
\hline \multirow{6}{*}{$\begin{array}{l}\text { Mothers' } \\
\text { Educational } \\
\text { Level }\end{array}$} & 1.Illiterate & 25 & 64,32 & 9,647 & \multirow{6}{*}{4} & \multirow{6}{*}{5.807} & $.000 *$ \\
\hline & 2.Primary School & 237 & 62,68 & 9,723 & & & $1-4$ \\
\hline & 3.Secondary School & 131 & 61,07 & 9,450 & & & $2-4$ \\
\hline & 4.Undergraduate (university) & 53 & 56,38 & 7,969 & & & \\
\hline & 5.MA & 6 & 57,00 & 6,870 & & & \\
\hline & Total & 452 & 61,49 & 9,622 & & & \\
\hline \multirow{6}{*}{$\begin{array}{l}\text { Fathers' } \\
\text { Educational } \\
\text { Level }\end{array}$} & 1.Illiterate & 13 & 58,62 & 6,590 & \multirow{6}{*}{4} & \multirow{6}{*}{4.021} & $.003^{*}$ \\
\hline & 2.Primary School & 154 & 63,47 & 9,458 & & & \\
\hline & 3. Secondary School & 179 & 61,28 & 10,445 & & & $5-2$ \\
\hline & 4.Undergraduate (university) & 85 & 60,42 & 8,883 & & & \\
\hline & 5. MA & 24 & 56,29 & 5,714 & & & \\
\hline & Total & 455 & 61,53 & 9,672 & & & \\
\hline \multirow{6}{*}{$\begin{array}{l}\text { Parents' } \\
\text { Economic } \\
\text { Level }\end{array}$} & $1.0-680 \mathrm{TL}$ & 25 & 61,28 & 14,752 & \multirow{6}{*}{4} & \multirow{6}{*}{10.459} & \multirow{6}{*}{$\begin{array}{l}.000 * \\
5-2,5-3 \\
4-3\end{array}$} \\
\hline & 2. 681-1000 TL & 57 & 62,61 & 10,982 & & & \\
\hline & 3. 1001-2000 TL & 126 & 65,53 & 9,826 & & & \\
\hline & $4.2001-3000 \mathrm{TL}$ & 118 & 59,83 & 8,790 & & & \\
\hline & 5. $3001 \mathrm{TL}$ and more & 130 & 58,45 & 6,990 & & & \\
\hline & Total & 456 & 61,44 & 9,726 & & & \\
\hline
\end{tabular}

$*_{\mathrm{p}}<0.05$ There is a significant difference.

As seen in the Table 6, there is a significant difference between the levels of Islamic moral values of pre-service teachers according to region $\left[\mathrm{F}={ }_{(0)} 17.035 ; \mathrm{P}=.000\right]$; mothers' educational level $\left[\mathrm{F}={ }_{(4)} 5.807 ; \mathrm{P}=.000\right]$; fathers' educational level $\left[\mathrm{F}={ }_{(4)} 4.021 ; \mathrm{P}=.003\right] ;$ and parents' economic level $\left[\mathrm{F}={ }_{(4)} 10.459 ; \mathrm{P}=.000\right]$. According to the Tukey $\mathrm{b}$ analysis done in order to identify the reason of the 
Titrek, O., Yalçınkaya, M., \& Bayrakcı, M. (2014). Islamic moral values of pre-service teachers for secondary schools. International Journal of Human Sciences, 11(1), 469-480. doi: 10.14687/ijhs.v11i1.2831

difference, it is seen that pre-service teachers whose parents live in Eastern Anatolia are different from the pre-service teachers whose parents live Mediterranean Region, the pre-service teachers whose parents live in Central Anatolia Region are different from the pre-service teachers whose parents live in Marmara Region, the pre-service teachers whose parents live in Aegean Region are different from the pre-service teachers whose parents live in Marmara Region and the pre-service teachers whose parents live in Mediterranean Region are different from the pre-service teachers whose parents live in Marmara Region. It is apparent that the level of Islamic moral values of pre - service teachers whose parents live in Eastern Anatolia Region $(\overline{\boldsymbol{x}}=66.11)$, Marmara Region $(\overline{\boldsymbol{x}}=65.53)$, Southeast Anatolia Region $(\overline{\boldsymbol{x}}=63.33)$ and Black Sea Region $(\overline{\boldsymbol{x}}=62.46)$ is higher than the level of Islamic moral values of pre - service teachers whose parents live in Aegean Region ( $\overline{\boldsymbol{x}}=57.15)$, Mediterranean Region $(\overline{\boldsymbol{x}}=56.96)$, Central Anatolia Region $(\overline{\boldsymbol{x}}=56.81)$.

According to the Tukey $\mathrm{b}$ analysis seen in the Table 5, there is a significant difference between the levels of Islamic moral values of pre-service teachers according to their mothers' educational level. The level of Islamic moral values of the pre-service teachers whose mothers are illiterate $(\overline{\boldsymbol{x}}$ $=64.32)$, had a primary school education $(\overline{\boldsymbol{x}}=62.68)$ and had a secondary school education $(\overline{\boldsymbol{x}}$ $=61.07)$ is higher than the level of Islamic moral values of the pre-service teachers whose mothers had a university education $(\overline{\boldsymbol{x}}=56.38)$ and MA education $(\overline{\boldsymbol{x}}=57.00)$.

According to the Tukey b analysis seen in the Table 5, there is a significant difference between the levels of Islamic moral values of pre - service teachers according to their fathers' educational level. The level of Islamic moral values of the pre-service teachers whose fathers had a primary school education $(\overline{\boldsymbol{x}}=63.47)$, had a secondary school education $(\overline{\boldsymbol{x}}=61.28)$ and had a university education $(\overline{\boldsymbol{x}}=60.42)$ is higher than the level of Islamic moral values of the preservice teachers whose fathers are illiterate $(\overline{\boldsymbol{x}}=58.62)$ and had a MA education $(\overline{\boldsymbol{x}}=56.29)$.

According to the Tukey b analysis seen in the Table 5, there is a significant difference between the levels of Islamic moral values of pre-service teachers according to their parents' economic level. The level of Islamic moral values of the pre-service teachers whose parents' economic level is 3000 TL is different from the ones whose parents' economic level is $681-1000$ TL and the ones whose economic level is $1001-2000$ TL. Also the level of Islamic moral values of the preservice teachers whose parents' economic level is 1001 - 2000 TL is different from the ones whose parents' economic level is 2001 - 3000 TL. In the Table 5, it is seen that the level of Islamic moral values of the pre-service teachers whose parents' economic level is $1001-2000 \mathrm{TL}$ $(\overline{\boldsymbol{x}}=65.53), 681-1000 \mathrm{TL}(\overline{\boldsymbol{x}}=62.61)$ and $0-680 \mathrm{TL}(\overline{\boldsymbol{x}}=61.28)$ is higher than the level of 
Titrek, O., Yalçınkaya, M., \& Bayrakcı, M. (2014). Islamic moral values of pre-service teachers for secondary schools. International Journal of Human Sciences, 11(1), 469-480. doi: 10.14687/ijhs.v11i1.2831

Islamic moral values of the pre-service teachers whose parents' economic level is $2001-3000$ TL $(\overline{\boldsymbol{x}}=59.83)$ and 3001 TL and more $(\overline{\boldsymbol{x}}=58.45)$.

\section{Results}

Considering the effects of teachers on students in the classes it is apparently seen that they are so important for the next generations because of the values they have. In this study, the aim is to examine the level of pre-service teachers moral according to Islamic moral values in Turkey whose population is approximately $99 \%$ Muslim.

In this study, it has is tried to determine how the level of Islamic moral values of pre-service teachers from different branches differ according to their gender, departments, universities, parents educational levels, families living areas and families economic levels. These pre-service teachers have been selected considering the rule of objectivities. Moreover, in some variables also we compared with attitudes towards Islam. Based on both variables results, we can claim that pre-service teachers' are religious people.

In the scale of "Islamic Moral Values" used in this study, while participants mostly agreed on the $16^{\text {th }}$ item "I feel sad when the rate of moral crimes increases", they agreed on the $11^{\text {th }}$ item "I avoid being friends with smokers" the least. There is no difference Islamic Moral Values of the participants according to genders. But women Islamic values and attitudes mean scores are higher than man. This research finding is similar with Çapçığlu ( 2009) research findings. Çapçığlu claim that (2009) women conservative religiousness attitudes are high but democratic attitudes are low in Teology Faculties in Turkey.

However, there is a significant difference between the levels of Islamic Moral Values of the participants according to their universities, departments, regions, parents' educational level and parents' economic level. Moreover, in the same sample, attitudes towards Islam mean score is higher than Islamic moral values. This means that pre-service teachers' attitudes are mostly based on Islam but their moral values are not as strong as their attitudes. As a result of one of the dimension of Titrek and Cobern' (2011) research which was conducted in Turkey and the USA, they found similar results about religion. Based on both research results we can say that Turkish pre-service teachers are really have high religious values and believe. 
Titrek, O., Yalçınkaya, M., \& Bayrakcı, M. (2014). Islamic moral values of pre-service teachers for secondary schools. International Journal of Human Sciences, 11(1), 469-480. doi: 10.14687/ijhs.v11i1.2831

It has been found that the level of Islamic Moral Values of the students in Sakarya University is higher than the students from Ege University. This can be environment affect. Sakarya University located in Sakarya City. This area is more conservative than İzmir (Eagen Sea Area). Morover, Sakarya is in Marmara region and results are very similar with pre-service teacher's families living area variable. In this study, it has been found that the level of Islamic Moral Values of the students whose families live in Marmara and East \& Southeast Anatolian Region is higher than the students whose families live in other regions. However, it is apparently seen that the level of Islamic Moral Values of the students whose families live in Aegean, Mediterranean and Central Anatolia Region is lower. Based on university and family living region variables, we can claim that Marmara and East and Southeast region peoples are more conservatives than other regions of Turkey. There is also significant difference between the levels of Islamic Moral Values of the students according to their families' educational levels. While the students, whose mothers are illiterate, have high level of Islamic Moral Values of the students whose mothers graduated from university is low.

The level of Islamic Moral Values of the students in Social Studies Teaching (SST) is higher than the students in Science Teaching (ST) and Language Teaching (LT). Another variable that affects the level of Islamic Moral Values is families living areas.

The picture is the same for fathers. While the students, whose fathers graduated from primary school, have high level of Islamic Moral Values of the students whose fathers have past graduate education is low. According to the variable "economic level of the families", the level of Islamic Moral Values of the students whose families' economic level is between 1001-2001 TL is the highest. At the same time, the level of Islamic Moral Values of the students, whose families' economic level is $3001 \mathrm{TL}$ and more, is the lowest.

\section{References}

Altınkurt, Y., \& Yılmaz, K. (2011). Öğretmen Adaylarının Öğretmenlerin Mesleki Etik Dışı Davranışlar ile İlgili Görüşleri. Mehmet Akif Ersoy Üniversitesi Eğitim Fakültesi Dergisi (22), 113-128.

Aşıkoğlu, N. (2000). İslam'a Göre İnancin Toplumdaki Yeri ve Rolü. İlahiyat Fakültesi Dergisi, 4(1).

Aydın, İ. (2003). Eğitim ve Ögrretimde Etik. Ankara: Pegem A Yayıncılık.

Aydın, M. (2011). Değerler, İşevleri ve Ahlak. EĞİTIM-BİR-SEN, 39-45.

Çapçığlu, İ. (2009). Socio-Political Attitudes and Religiosity: A Survey in the Sample of Divinity Faculties. Illabiyat Fakëiltesi Dergisi 14:1 (2009), 143-180.

Çetinkaya, B. A. (2007). IX. Kur'ân Sempozyumu (14-16 Nisan 2006) "Kur'ân'da Ahlâkî Değerler". C.Ü İlabiyat Fakültesi Dergisi, 6(1), 413-416. 
Titrek, O., Yalçınkaya, M., \& Bayrakcı, M. (2014). Islamic moral values of pre-service teachers for secondary schools. International Journal of Human Sciences, 11(1), 469-480. doi: 10.14687/ijhs.v11i1.2831

Dilmaç, B., Bozgeyikli, H., \& Çıkılı, Y. (2008). Öğretmen Adaylarının Değer Algılarının Farklı Değişkenler Açısından İncelenmesi. Değerler Eğitimi Dergisi, 69-91.

Francis, L. J., Jones, S. H. \& Craig, C. L. (2004). The Relationship between Psychological Type and Attitude toward Christianity, Personality and Religion, 26, 15-34(20).

Francis, L. J., Şahin, A. \& Al-Failakawi (2008). Psychometric properties of two Islamic measures among young adults in Kuwait:the SahinFrancis Scale of Attitude toward Islam and the Sahin Index of Islamic Moral Values. The Journal of Muslim Mental Health, 3 (9-24).

Ok, Ü. (2011). Dini tutum ölçeği: ölçek geliştirme ve geçerlik çalısması. Uluslararası İnsan Bilimleri Dergisi. [Bağlantıda]. 8:2. Erişim: http://www.insanbilimleri.com

Pelit, E \& Güçer, E. (2006). The perception of teacher candidates concerning unethical behaviours about teaching profession and factors incling teachers unethical behavior. Ticaret ve Turizm Egitim Fakültesi Dergisi, 2.

Titrek, O. \& Cobern, W. W. (2011). Valuing Science: A Turkish-American Comparison. International Journal of Science Education. 33(3), 1 February 2011, pp. 401-421

Uygun, S. (2009). “The Democracy Education at Schools and Pre-service Teachers' Observations to the Democratic Attitudes and Behaviors in School", International Symposium on Sustainable Development (June 9-10 2009), Sarajevo, 138-144, International Burch University.

Uysal, E. (2003). Değerler Üzerine Bazı Düşünceler ve Bir Erdem Tasnifi Denemesi: Insanî Erdemlerİslâmî Erdemler. Uludağ Üniversitesi İlabiyat Fakülltesi Dergisi, 12(1), 51-69.

Ünal, E. (2011). Examining the relationship between pre-service teachers' ethical reasoning levels and their academic dishonesty levels: A structural equation modelling approach. Educational Research and Reviews, Vol. 6 (19), 983-992, 19 November, 2011.

Yazar, T. (2012). Opinions of the Prospective Teachers about Values. Pegem Eğitim ve Ögrretim Dergisi / 2, (1).

Yazıc1, K. (2006). Değerlerin Eğitimine Genel Bir Bakış. Türklük Bilimi Araștırmaları(19), 499-522.

Yiğit E. Ö.\& Çolak, K. (2010). Democratic Attitudes of Social Studies Pre-service Teachers Educational Research Association, The International Journal of Research in Teacher Education, 1(Special Issue): 8295ISSN: 1308-951X.

Yürütücü, A., \& Gürbüz, H. (2001). Hekimlerin Ahlaki Değerleri ile Meslek Etiğinin İstatistiksel Olarak İncelenmesi. Süleyman Demirel Üniversitesi İktisadi ve İdari Bilimler Fakültesi, 6(1), 157-172.

Zehir Topkaya, E. and Yavuz, A. (2011). Democratic Values and Teacher Self-Efficacy Perceptions: A Case of Pre-Service English Language Teachers in Turkey. Australian Journal of Teacher Education: 36. 